\title{
The stratigraphic range of the index ammonite Pachydiscus neubergicus (von Hauer, 1858) in the type area of the Maastrichtian Stage ${ }^{1}$
}

\author{
J.W.M. Jagt ${ }^{1} \&$ W.M. Felder ${ }^{2}$ \\ 1 Natuurhistorisch Museum Maastricht, P.O. Box 882, NL-6200 AW Maastricht, \\ the Netherlands; e-mail: mail@nhmmaastricht.nl \\ 2 Oude Trichterweg 26, NL-6294 ALVijlen, the Netherlands \\ 3 Contribution no. 14 of the 'Vijlen Werkgroep'
}

Received: May 2001; accepted: September 2001

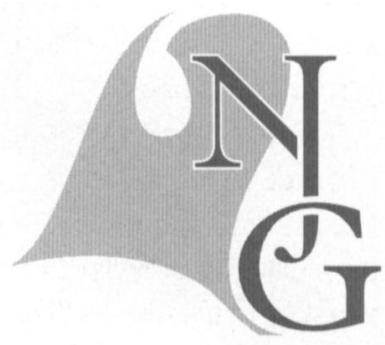

\begin{abstract}
In the extended type area of the Maastrichtian Stage (southern Limburg, the Netherlands; provinces of Limburg and Liège, Belgium; Aachen area, Germany), the pachydiscid Pachydiscus (P.) neubergicus (von Hauer, 1858) ranks amongst the rarer species of Campanian-Maastrichtian ammonites. To date, just four specimens are known, which show $P$. (P.) neubergicus in this area to have been confined to the Vijlen Member (Intervals 0-6, Gulpen Formation). This would correspond to the basal sumensis Zone to the lower cimbrica Zone, or tegulatus/junior Zone, depending on placement of the Lower/Upper Maastrichtian boundary. Material available has been collected in recent years at the CBR-Lixhe (Liège, Belgium) and ENCI-Maastricht bv (Maastricht) quarries as well as from outcrop 62D-26 at Vijlenerbosch (Vijlen, the Netherlands). Records of $P$. (P) neubergicus, the proposed index for the base of the Maastrichtian Stage, from elsewhere in Europe (northern Spain, SW France, Austria, Denmark, Bulgaria), suggest it to have been fairly long-ranging and show local first occurrences to have been diachronous.
\end{abstract}

Key words: Maastrichtian, ammonites, stratigraphic range

\section{Introduction}

Although pachydiscids are comparatively well represented in the Late Cretaceous ammonite faunas known to date from the extended Maastrichtian type area, $P$. (P.) neubergicus is one of the rarer species. Jagt (2002, fig. 6a-c, e, f) recorded two crushed, fragmentary internal moulds from the lower portion of the Vijlen Member (= Interval 6, sensu P.J. Felder \& Bless, 1994) as exposed at the CBR-Lixhe quarry (Liège, Belgium; see Fig. 1). In the present paper, two additional specimens of $P$. (P.) neubergicus are described and illustrated. One is from 2-3 metres above the Zonneberg Horizon (Vijlen Member) as exposed at the ENCI-Maastricht bv quarry, the other from $c$. $1.5 \mathrm{~m}$ above the base of the Vijlen Member in outcrop no. $62 \mathrm{D}-26$ at Vijlenerbosch, south of Vijlen. Correlation with the Vijlen Member type region suggests that P. (P.) neubergicus in the Maastrichtian type area ranged from the basal sumensis Zone to the lower cimbrica Zone (sensu Keutgen, 1996) or tegulatus/junior Zone, i.e. middle to upper Lower Maastrichtian, or lower Upper Maastrichtian. Most authors have considered Interval 6 (sensu P.J. Felder \& Bless, 1994) of the Vijlen Member to be of early Late Maastrichtian age. Keutgen (1996), however, equated this with the Belemnella cimbrica Zone, of late Early Maastrichtian age. This matter will be discussed in more detail below. 


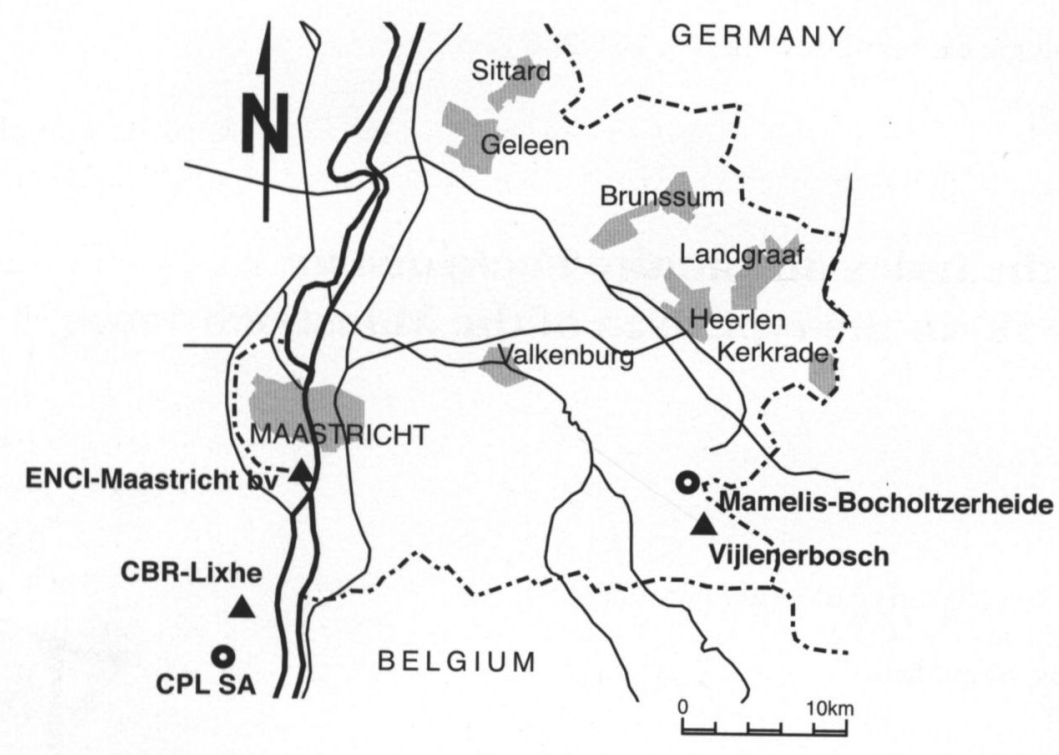

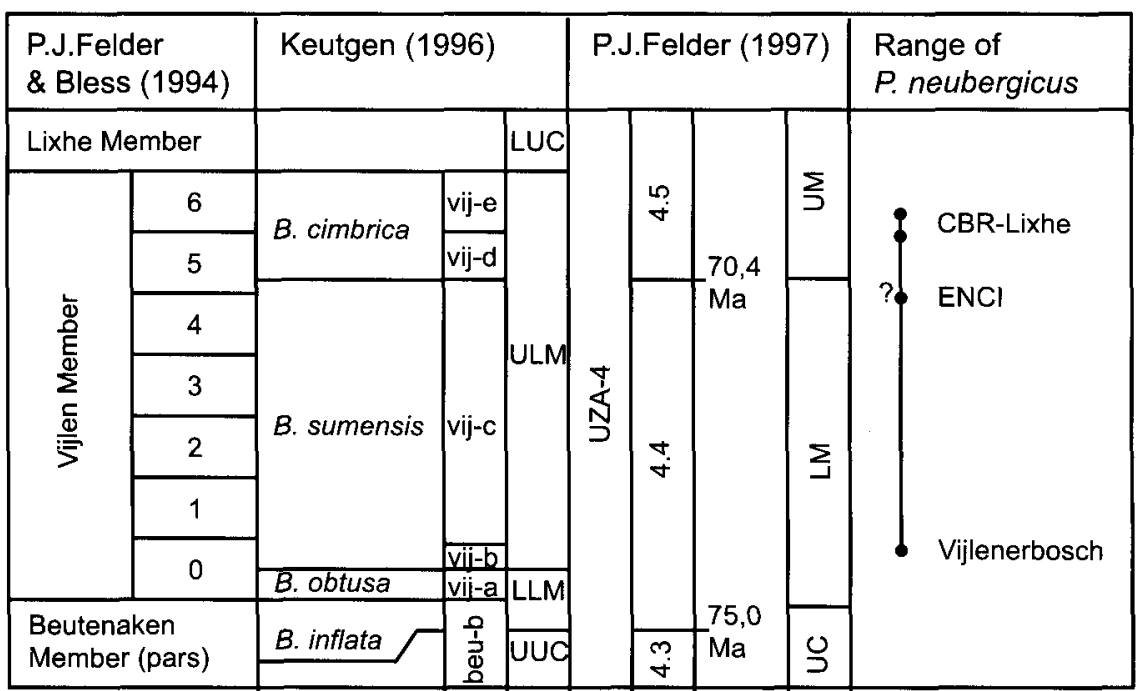

Fig. 1. Schematic map of southern Limburg (the Netherlands) and contiguous areas, showing occurrences of Pachydiscus (P.) neubergicus (solid triangles) and other localities referred to in the text.

For the Vijlen Member the following subdivisions are illustrated:

- into Intervals (0 to 6) (after P.J. Felder \& Bless, 1994);

- into belemnite zones (Belemnella inflata, B. obtusa, B. sumensis and B. cimbri$c a$ ), informal faunal zones (vij-a to vije), as well as chronostratigraphic interpretation of these (UUC - upper Upper Campanian; LLM - lower Lower Maastrichtian; ULM - upper Lower Maastrichtian; LUC - lower Upper Maastrichtian) (all after Keutgen, 1996);

into (super)cycles, with absolute age assignment and chronostratigraphic interpretation (UC - Upper Campanian; LM - Lower Maastrichtian; UM Upper Maastrichtian) (after P.J. Felder, 1997).

The range of $P$. (P.) neubergicus, as known to date, is also indicated.

\section{Systematic description}

\section{Abbreviations}

To denote the repositories of material referred to in the text the following abbreviations are used:

GBA Geologische Bundesanstalt, Wien (Austria);

NHMM Natuurhistorisch Museum Maastricht (GK - W.M. Felder Colln; JJ - J.W.M. Jagt Colln).

\section{Measurements}

$\mathrm{D}=$ diameter; $\mathrm{Wb}=$ whorl breadth; $\mathrm{Wh}=$ whorl height; $\mathrm{U}=$ umbilical diameter; all in millimetres.
Family Pachydiscidae Spath, 1922

Genus and subgenus Pachydiscus (Pachydiscus) von Zittel, 1884

\section{Type species}

Ammonites neubergicus von Hauer, 1858, p. 12 (partim), pl. 2, figs 1-3; pl. 3, figs 1-2, by subsequent designation of de Grossouvre (1894, p. 177).

Pachydiscus (Pachydiscus) neubergicus (von Hauer, 1858)

Figs 2,3

^1858 Ammonites neubergicus von Hauer, p. 12 (partim), pl. 2, figs 1-3, non pl. 3, figs 1, 2 .

1986 Pachydiscus (Pachydiscus) neubergicus (von Hauer, 1858) - Kennedy \& Summesberger, p. 189 , pl. 2, figs 1,2 ; pl. 3, figs $1-3$; pl. 4 , figs $1-$ 
5; pl. 5, figs 1, 4, 5; pl. 6, figs $1,2,5$; pl. 15, figs 7,8 ; text-fig. $5 \mathrm{a}, \mathrm{b}$ (with additional synonymy).

1993 Pachydiscus (Pachydiscus) neubergicus neubergicus (Hauer, 1858) - Ward \& Kennedy, p. 30, figs $25.9-25.12,25.14,25.16-25.18,27.3-$ 27.5, 27.7, 28.1-28.3, 30.4, 30.6.

2001 Pachydiscus neubergicus - Kennedy \& Odin, p. 478, pl. 1 , fig. 8.

2001 Pachydiscus neubergicus (von Hauer, 1858) Courville \& Odin, p. 533, pl. 6, figs 48-50.

2001 Pachydiscus neubergicus - Odin et al., p. 550, pl. 2, top figure.

2001 Pachydiscus neubergicus (von Hauer, 1858) Küchler et al., p. 726, pl. 3, figs 1-3, 6, 7 .

Type

Lectotype, designated by de Grossouvre (1894, p. 209 ), is GBA 1858.01.6, the original of von Hauer (1858, p. 12, pl. 2, figs 1, 2).

\section{Material}

Two crushed, fragmentary specimens are known from the CBR-Lixhe quarry: NHMM JJ 7220 [base Vijlen Member + c. $2 \mathrm{~m}$; see Jagt, 2002, fig. 6a, b] and NHMM 1997094a, b [base Vijlen Member + c. 4.75 m; see Jagt, 2002, fig. 6c, e, f; leg. G. Cremers]. Two additional specimens, NHMM GK 9353 and NHMM 2001 055, from Vijlenerbosch and ENCIMaastricht bv quarry, respectively, are here illustrated and described.

\section{Description}

Both specimens are preserved as composite moulds and are more or less distorted, which is why measurements given below are approximate.

NHMM GK 9353 (Fig. 2) is a slightly crushed composite mould, $\mathrm{D}=72.1 \mathrm{~mm}$, wholly septate and relatively involute, with $U$ c. $23 \%$ of diameter. Umbilical wall low and rounded, umbilical shoulder more narrowly rounded, inner flanks weakly convex, outer flanks convergent and venter narrowly rounded. Whorl section compressed, oval (Wb:Wh ratio 0.68 ). As preserved, there are 6 primary ribs per half whorl (i.e. 12 or more per whorl); these arise at umbilical wall, where they are concave, and strengthen on umbilical shoulder, giving rise to narrow, distant umbilical bullae. These extend across the inner third of the flank, and become concave as size increases. Arising from these bullae are narrow primary ribs, straight and prorsiradiate on the inner two thirds of the flanks, and bifurcate at variable points on outer flank; occasional intercalated ribs arise on outer flank. A total of $c .27$ ventral ribs per half whorl may be counted at this growth stage; these are all of comparable strength and cross the venter in a shallow convexity.

NHMM 2001055 (Fig. 3) is a larger, laterally crushed composite mould, $\mathrm{D}=102.5 \mathrm{~mm}$, wholly septate and comparatively involute with $U=29.6 \%$ of diameter, and $c$. two-thirds of previous whorl covered. Umbilicus shallow; umbilical wall low and rounded, slightly undercut; umbilical shoulder narrowly rounded, inner flanks faintly convex, outer flanks convergent and venter narrowly rounded.

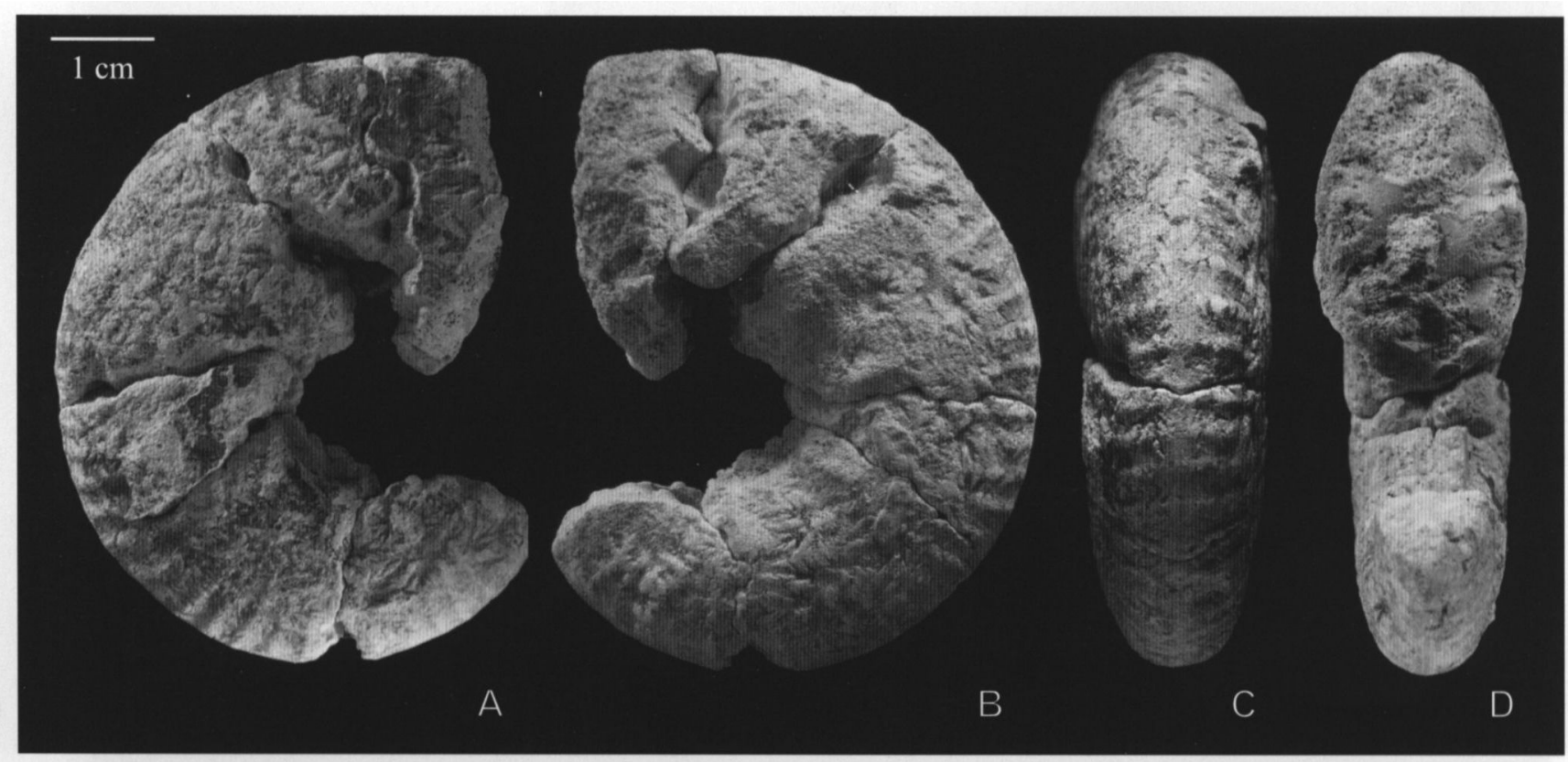

Fig. 2. Pachydiscus (P.) neubergicus (von Hauer, 1858), NHMM GK 9353 (W.M. Felder Colln), outcrop 62D-26 at Vijlenerbosch (Vijlen, the Netherlands), October 1999; Gulpen Formation, Vijlen Member, lower sumensis Zone. 


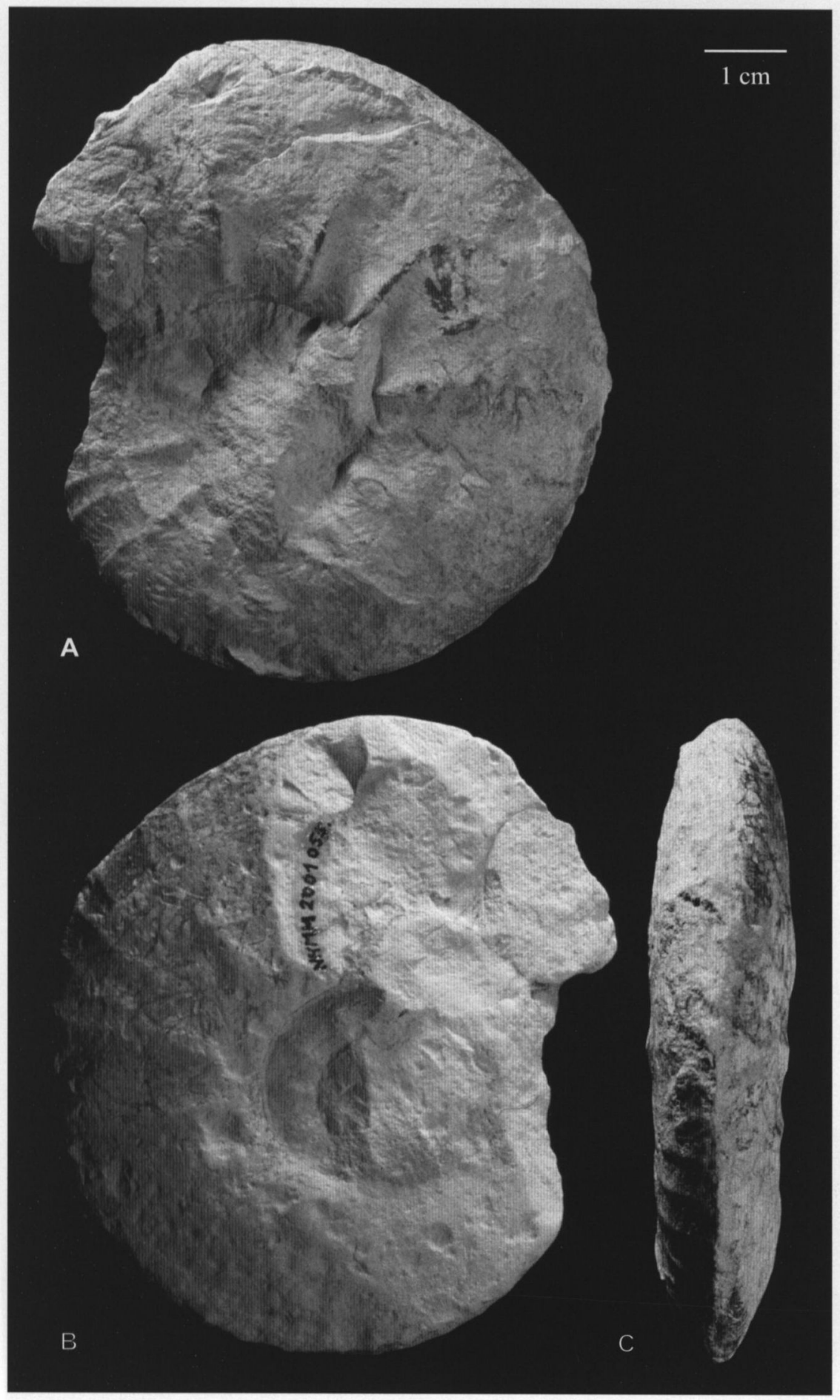

Fig. 3. Pachydiscus (P.) neubergicus (von Hauer, 1858), NHMM 2001055 (leg. R. Meuris), ENCI-Maastricht bv quarry (Maastricht, the Netherlands), 24 March 2001; Gulpen Formation, Vijlen Member, Zonneberg Horizon $+2-3 \mathrm{~m}$, ?cimbrica Zone.

Whorl section compressed, oval. As preserved, there are 13 primary ribs per whorl; these arise at umbilical wall, sweep backwards and strengthen across umbilical shoulder, and give rise to fairly strong, long distant umbilical bullae. These extend across the inner third of the flank, are straight and prorsiradiate on earlier whorls but become relatively narrower and more or less concave, or remain straight, as size increases. At the largest diameter seen, bullae become elongate, extend to mid-flank, and secondaries/intercalatory ribs become less numerous; in addition, rib- bing appears to weaken over the venter. Arising from these bullae are narrow primary ribs; these are straight and prorsiradiate or occasionally concave on the inner flanks, and bifurcate at variable points on the outer flank. All ribs, of comparable strength, pass the venter in a shallow convexity. There is an estimated total of 42-44 ventral ribs per whorl, corresponding to 13 umbilical bullae, as preserved.

Both specimens show partially preserved sutures; these are typically deeply and intricately subdivided. 


\section{Discussion}

As far as whorl section, ornament and proportions are concerned, there is a close match between topotypes of $P$. (P.) neubergicus and NHMM GK 9353 and NHMM 2001 055. Kennedy \& Summesberger (1986) noted for material from Krampen (Neuberg an der Mürz, Austria): oval whorl section, 14-17 umbilical bullae and 48 to almost 60 ventral ribs. Specimens from the Bay of Biscay sections (Spain, France), up to $160 \mathrm{~mm}$ in diameter, have $\mathrm{U}=30 \%$ of diameter, 14-16 primary ribs in middle growth stages and 20-27 ventral ribs per half whorl (Ward \& Kennedy, 1993). Material from Tercis (Landes) (see Kennedy \& Odin, 2001; Courville \& Odin, 2001; Odin et al., 2001) and northern Spain (Navarra; see Küchler et al., 2001) is similar as well.

Pachydiscus (P.) armenicus Atabekian \& Akopian, 1969 , which partially overlaps in range with $P$. (P) neubergicus in the Bay of Biscay sections, has more numerous umbilical bullae (16-20) and ventral ribs (6273) per whorl. A single fragmentary phragmocone from the Vijlen Member (base + 0-5 m; Interval 6) at the CPL SA quarry (NHMM PNG1, N. Keutgen Colln) may be referred here (see Jagt, 2002, fig. 6d). To date, this species is known from Armenia (Azizbek region), the Bay of Biscay sections, Tercis (Landes, France), Pyrénées-Atlantiques, Bulgaria, and ?Kamchatka/Sakhalin, ranging from the Lower to the upper Upper Maastrichtian.

Following the 'Second International Symposium on Cretaceous Stage Boundaries' (Brussels, September 1995), the first appearance datum (FAD) of $P$. (P) neubergicus, has been proposed to define the base of the Maastrichtian Stage (see Odin, 2001). For practical reasons, in NW European sections (i.e. in boreal/temperate settings), the FAD of the coleoid cephalopod Belemnella lanceolata (von Schlottheim, 1813) marks the base of the Maastrichtian, in the near-absence of ammonites. Nannofossil analyses for sections in northern Germany (see Schönfeld et al., 1996, fig. 3) show this FAD to be within nannofossil zone CC23a. Correlation with strata in the (extended) Maastrichtian type area are hampered by the fact that the uppermost Campanian-lowermost Maastrichtian interval there is characterised by hiatuses, condensation and/or considerable reworking (see below).

At Tercis and in northern Spain, $P$. (P.) neubergicus first occurs in the lower Lower Maastrichtian, equivalent of the nannofossil zone CC23a (UC16) (see Küchler, 2000; Wagreich et al., 2002). In other sections (e.g., Bjala, Bulgaria) the species appears to range up as high as nannofossil zone CC25b/c
(UC20), of Late Maastrichtian age. Wagreich et al. (2003) noted that, on account of the long range of $P$. (P.) neubergicus, local first occurrences in non-continuous ammonite sections might be diachronous.

Pachydiscus (P.) neubergicus is now known from Denmark, northern (northeast) Germany, ?southern Belgium (Mons Basin), Tercis (Landes, France), Bay of Biscay sections (Spain, France), northeast and ?southeast Spain, Austria, the ?Czech Republic, central Poland, Bulgaria, the Ukraine, European Russia, Baluchistan, southern India, Nigeria, Zululand, Madagascar, the United Arab Emirates/Oman border region, New Jersey, and ?Sakhalin.

\section{Local stratigraphy}

All material of $P$. (P.) neubergicus from the type area of the Maastrichtian Stage known to date is from the Vijlen Member. Although recent studies (e.g., Keutgen \& van der Tuuk, 1991; P.J. Felder \& Bless, 1994; Keutgen, 1996; P.J. Felder, 1997) have done much to unravel the intricate facies relationships in the type area of the unit and suggested correlations to other areas, based mainly on coleoid cephalopods, many questions still remain. In order to determine the stratigraphic range of $P$. (P.) neubergicus in this area, a few of these issues need to be addressed here.

As noted above, strata of latest Campanian and earliest Maastrichtian age are poorly represented in the area. The main portion of the Beutenaken Member, underlying the Vijlen Member, is of late Late Campanian age, as based on calcareous nannoplankton and coleoid cephalopods (Verbeek, 1983; Keutgen \& van der Tuuk, 1991; Keutgen, 1996; Keutgen \& Jagt, 1999). For sections in Norfolk (England), Christensen $(1995,1996)$ recorded three successive evolutionary stages for the coleoid Belemnitella minor:

- minor I, occurring in the Catton Sponge Bed, Beeston Chalk Member and lower part of Paramoudra Chalk Member (= polyplocum and lower langei zones of Schulz et al., 1984);

- minor II, occurring in the Paramoudra Chalk Member (= upper langei and grimmensis/granulosus zones);

- minor III, occurring in the early Early Maastrichtian (lanceolata to obtusa zones of Schulz, 1979).

In the extended Maastrichtian type area, B. minor first occurs in the Beutenaken Member, early forms (= $m i$ nor I) being known from Teuven (NE Belgium). Keutgen (1996) referred material from Bovenste Bos, Slenaken and Pesaken-Crapoel to minor II or minor III. Keutgen (1996) referred the major portion of the Beutenaken Member to his Belemnitella minor Zone, with minor I from the lower part corresponding to 
populations from the upper Beeston Chalk Member or the basal Paramoudra Chalk Member (Christensen, 1995). The uppermost part of the Beutenaken Member is of Early Maastrichtian age, showing Keutgen's minor Zone to correspond with the langei, grimmensis/granulosus and basal lanceolata zones. This in turn implies Beutenaken sedimentation to have started in the upper part of nannofossil zone CC22C. Keutgen's Belemnella inflata Zone, represented in the uppermost Beutenaken Member, correlates roughly with the lanceolata and pseudobtusa zones (CC23a).

Keutgen \& van der Tuuk (1991) recorded early forms of Belemnella obtusa Schulz, 1979 from Beutenaken (Habets quarry), where $c .2$ metres above the upper limit of the quarry face the Bovenste Bosch Horizon may be exposed by removing scree. The base of the Vijlen Member has a $c .0 .1 \mathrm{~m}$ thick level with $B$. obtusa there; a similar situation occurs at the Gelissen quarry at Beutenaken (outcrop no. 62C-27). Schulz (1979) mentioned middle obtusa Zone belemnites from the Beutenaken area (Gelissen quarry), while Keutgen (1996) also recorded Belemnella lanceolata and B. minor (sensu Christensen, 1995) from this region, an association typical of the lower obtusa Zone, corroborated by mean values for 'populations' of $B$. obtusa. Keutgen's (1996) Belemnella obtusa Zone characterises the lowermost Vijlen Member (= Interval 0, sensu P.J. Felder \& Bless, 1994; see Fig. 1). His Belemnella sumensis Zone ranges from the base of Interval 0 to within Interval 5, while the Belemnella cimbrica Zone encompasses Interval 5 and 6, and corresponds to the NW German cimbrica and fastigata zones. The presence of the scaphitid ammonite Acanthoscaphites (Euroscaphites) varians blaszkiewiczi, whose FAD defines the base of Keutgen's unit vij-e (see Fig. 1), allows the lower boundary of the fastigata Zone to be drawn roughly near the base of Interval 6 . The last appearance datum of B. cimbrica is used to situate the Lower/Upper Maastrichtian boundary within the uppermost Vijlen or lowermost Lixhe 1 members.

In NW Europe, authors have generally used the FAD of Belemnitella junior Nowak, 1913 to define the base of the Upper Maastrichtian. For practical reasons, the Lower/Upper Maastrichtian boundary in sections in NW Germany was placed at level M900 (see Schönfeld et al., 1996), which is the base of the tegulatus/junior Zone. However, in the extended Maastrichtian type area, the earliest representatives of the junior group (sensu Keutgen, 1996) are recorded from the sumensis Zone (i.e. middle Lower Maastrichtian) portion of the Vijlen Member. For this reason, Keutgen (1996) recommended that other events, e.g. the last appearance datum (LAD) of B. cimbrica or the FAD of A.v. blaszkiewiczi, be used to determine the position of the Lower/Upper Maastrichtian boundary in the area. This LAD is within Interval 6 of the Vijlen Member. In addition, Keutgen noted the occurrence within the Lixhe 1 Member of the benthic foraminifer Reussella cimbrica (Troelsen, 1937), index of the 'Pseudouvigerina cimbrica Zone' of early Late Maastrichtian age in Denmark.

Pending a revision of representatives of the Belemnitella junior group (Christensen et al., in prep.), and awaiting the results of large-scale sampling of the Vijlen Member at the ENCI-Maastricht bv quarry, neither of the two interpretations is here favoured.

What then is the range of $P$. (P) neubergicus in the Maastrichtian type area? NHMM JJ 7220 and NHMM 1997094a, b are both from the lower $4.75 \mathrm{~m}$ of the Vijlen Member at the CBR-Lixhe quarry, i.e. basal portion of Interval 6 . This would correspond either to the cimbrica Zone or the tegulatus/junior Zone (CC25).

NHMM GK 9353 comes from c. $1.5 \mathrm{~m}$ above the base of the Vijlen Member at Vijlenerbosch, and c. 0.2 $\mathrm{m}$ above a well-developed hardground. This hardground may correspond to one of the omission surfaces at the Altembroeck section (sumensis Zone; see Jagt et al., 1995), but this needs to be checked. It would appear that the Vijlenerbosch occurrence matches either the upper portion of Keutgen's (1996) unit vij-b or the lower part of unit vij-c, of sumensis Zone age. This, in turn, would correspond to Interval 0 or Interval 1 of P.J. Felder \& Bless (1994). The lowermost portion of the sumensis Zone as defined in northern Germany (Kronsmoor section) equates with the upper part of nannofossil zone CC23b, the remainder of the zone with CC24 (see Schönfeld et al., 1996).

Unfortunately, NHMM 2001055 was collected loose. However, based on field observations at the time of collecting and on preservation and facies type, the specimen must have come from $2-3 \mathrm{~m}$ above the Zonneberg Horizon. W.M. Felder \& Bosch (2000) considered this horizon (see Fig. 2) to correspond to the basal, glauconite-rich portion of the Vijlen Member at Lixhe and Eijsden (= Interval 6 ). Whether or not this assumption is correct yet needs to be determined.

For a number of years now, some 15 metres assigned to the Vijlen Member have been exposed at the ENCI-Maastricht bv quarry. A preliminary sample series from this section, starting at the Zonneberg Horizon, taken by one of us (WMF) was analysed for benthic foraminifera by Jan Meessen (see Jagt et al., 1999), who recognised three intervals (from bottom to top): 
- interval without Bolivinoides draco (Marsson, 1878), but with Stensioeina pommerana Brotzen, 1936;

- interval with $B$. draco and S. pommerana;

- interval with $B$. draco, but without $S$. pommerana.

The absence of $S$. pommerana in the highest interval suggests correlation with the base of Wicher's (1953) so-called 'Stensiöinen-freie Bereich' in NW Germany. Koch (1977) correlated Wicher's 'Stensiöinen-freie Bereich' with the uppermost Lower to the lower part of the upper Upper Maastrichtian. However, at Hemmoor (NW Germany), Hofker (1961) found the highest occurrence of Stensioeina to equate with the M900 marl layer, which marks the Lower/Upper Maastrichtian boundary there (see Schönfeld et al., 1996). On benthic foraminifer evidence, the Lower/ Upper Maastrichtian boundary at ENCI may thus be placed at the top of the interval with both B. draco and $S$. pommerana. In this respect, it should also be noted that Weiss (1999) pointed out that in the uppermost part of the Lower Maastrichtian in the KronsmoorHemmoor sections, near the top of the Belemnella cimbrica Zone, S. pommerana suddenly disappeared, and that the 'Stensioeina-free section' characterised the lower part of the Upper Maastrichtian.

A comparison of the ENCI section with the type section of the Vijlen Member at Mamelis-Bocholtzerheide shows the following picture. In Interval 6 there, $B$. draco and $S$. pommerana co-occur, which means that the highest part of the Vijlen Member type section is correlatable with the interval at the ENCI quarry between the first occurrence of $B$. draco and the last occurrence of $S$. pommerana. To refine this picture additional studies of belemnite 'populations', collected bed by bed, and strontium isotope analyses are needed.

Associated ammonites at ENCI include poorly preserved baculitids (at least two species), and a few scaphitids (Hoploscaphites constrictus (J. Sowerby, 1817) and feletzkytes ?n.sp.; Kennedy \& Jagt, in prep.), as well as nautiloids.

To sum up, $P$. (P.) neubergicus in the Maastrichtian type area appears to range from the (basal) sumensis Zone to the lower cimbrica Zone (or lower tegulatus/junior Zone), depending on the definition of the Lower/Upper Maastrichtian boundary in the area.

\section{Acknowledgements}

We thank R.W. Dortangs (Amstenrade) for photography, R. Meuris (Beerzel) for donation of NHMM 2001 055, and A.S. Schulp (Natuurhistorisch Museum Maastricht) for drafting of figures.

\section{References}

Atabekian, A.A. \& Akopian, V.T., 1969. Late Cretaceous ammonites of the Armenian SSR (Pachydiscidae). Izvestiya AN Armyanskoj SSR, Nauki o Zemle 6: 3-20 (in Russian).

Brotzen, F., 1936. Foraminiferen aus dem schwedischen Untersenon von Eriksdal in Schonen. Sveriges geologiska Undersökning C396: 1-199.

Christensen, W.K., 1995. Belemnitella from the Upper Campanian and Lower Maastrichtian Chalk of Norfolk, England. Special Papers in Palaeontology 51: 1-84.

Christensen, W.K., 1996. A review of the Upper Campanian and Maastrichtian belemnite biostratigraphy of Europe. Cretaceous Research 17: 751-766.

Courville, P. \& Odin, G.S., 2001. Les ammonites spiralées du Campanien et du Mastrichtien de Tercis les Bains (Landes, France). In: Odin, G.S. (Ed.): The Campanian-Maastrichtian Stage Boundary. Characterisation at Tercis les Bains (France) and Correlation with Europe and other Continents [Developments in Palaeontology and Stratigraphy, 19]. Elsevier (Amsterdam): 529-549.

Felder, P.J., 1997. The Vijlen Chalk Member (Maastrichtian, Late Cretaceous) in the Meuse-Rhine Euregion. Annales de la Société géologique de Belgique 119(1996): 119-133.

Felder, P.J. \& Bless, M.J.M., 1994. The Vijlen Member (early Early to early Late Maastrichtian) in its type area around Vijlen and Mamelis (South-Limburg, The Netherlands). Annales de la Société géologique de Belgique 116(1993): 61-85.

Felder, W.M., 1977. Ons Krijtland Zuid-Limburg. I. Van Epen naar Vaals. Geologie van een toeristenweg. Koninklijke Nederlandse Natuurhistorische Vereniging, Wetenschappelijke Mededelingen 55: 1-36.

Felder, W.M. \& Bosch, P.W., 1998. Geologie van de St. Pietersberg bij Maastricht. Grondboor en Hamer 52: 53-63.

Felder, W.M. \& Bosch, P.W., 2000. Geologie van Nederland, deel 5. Krijt van Zuid-Limburg. Nederlands Instituut voor Toegepaste Geowetenschappen TNO (Delft/Utrecht): $190 \mathrm{pp}$.

Grossouvre, A. de, 1894. Recherches de la craie supérieure, 2. Paléontologie. Les ammonites de la craie supérieure. Mémoires du Service de la Carte géologique détaillée de France. Imprimerie nationale (Paris): $264 \mathrm{pp}$.

Hauer, F. von, 1858. Über die Cephalopoden der Gosauschichten. Beiträge zur Paläontologie von Österreich 1: 7-14.

Hofker, J., 1961. Die Foraminiferen-Fauna der Gruben Hemmoor und Basbeck. Paläontologische Zeitschrift 35: 123-145.

Jagt, J.W.M., Deckers, M., Dhondt, A.V., Dortangs, R.W., Felder, P.J., Felder, W.M., Jäger, M., Keutgen, N., Kuypers, M., Michels, G., Reynders, J., Simon, E., van der Ham, R., van Knippenberg, P. \& van Neer, R., 1995. Preliminary report of field work at Altembroeck (NE Belgium, early Maastrichtian) by the Working Group Beutenaken/Vijlen members. Geological Survey of Belgium, Professional Paper 1995/1 (276): 1-20.

Jagt, J.W.M., Dortangs, R.W., Felder, W.M. \& Meessen, J.P.M.T., 1999. The Lower/Upper Maastrichtian boundary at the ENCIMaastricht bv quarry (Maastricht, the Netherlands). In: Schulp, A.S., Jagt, J.W.M. \& Graaf, D.T. de (Eds): The 150th anniversary of the Maastrichtian Stage: a celebratory conference. Natuurhistorisch Museum Maastricht, 17-21 November 1999. Conference programme, abstracts and field guide: $39-40$.

Jagt, J.W.M., 2002. Late Cretaceous ammonite faunas of the Maastrichtian type area. In: Summesberger, H., Histon, K. \& Daurer, A. (Eds): Cephalopods - present and past. Abhandlungen der geologischen Bundesanstalt Wien 57(2001): 509-522.

Kennedy, W.J. \& Odin, G.S., 2001. Report on a preliminary blind 
test on ammonites collected from Tercis les Bains (Landes, France). In: Odin, G.S. (Ed.): The Campanian-Maastrichtian Stage Boundary. Characterisation at Tercis les Bains (France) and Correlation with Europe and other Continents (Developments in Palaeontology and Stratigraphy, 19). Elsevier (Amsterdam): 478-482.

Kennedy, W.J. \& Summesberger, H., 1986. Lower Maastrichtian ammonites from Neuberg, Steiermark, Austria. Beiträge zur Paläontologie von Österreich 12: 181-242.

Keutgen, N., 1996. Biostratigraphie, Paläoökologie und Invertebratenfauna des Untermaastricht von Aachen (Westdeutschland) und angrenzenden Gebieten (Südostniederlande, Nordostbelgien). Aachen (Shaker Verlag): iv $+213 \mathrm{pp}$.

Keutgen, N. \& Jagt, J.W.M., 1999. Late Campanian belemnite faunas from Liège-Limburg (NE Belgium, SE Netherlands). Geological Survey of Belgium, Professional Paper 1998/2 (287): 131 .

Keutgen, N. \& van der Tuuk, L.A., 1991. Belemnites from the Lower Maastrichtian of Limburg, Aachen and Liège. Mededelingen van de Rijks Geologische Dienst 44(1990): 1-39.

Koch, W., 1977. Biostratigraphie in der Oberkreide und Taxonomie von Foraminiferen. Geologisches Jahrbuch A38: 11-123.

Küchler, T., 2000. Upper Cretaceous of the Barranca (Navarra, northern Spain); integrated litho-, bio- and event stratigraphy. Part II: Campanian and Maastrichtian. Acta geologica polonica 50: 441-499.

Küchler, T., Kutz, A. \& Wagreich, M., 2001. The CampanianMaastrichtian boundary in northern Spain (Navarra province): the Imiscoz and Erro sections. In: Odin, G.S. (Ed.): The Campanian-Maastrichtian Stage Boundary. Characterisation at Tercis les Bains (France) and Correlation with Europe and other Continents [Developments in Palaeontology and Stratigraphy, 19]. Elsevier (Amsterdam): 723-744.

Marsson, T., 1878. Die Foraminiferen der weissen Kreide der Insel Rügen. Mitteilungen des naturwissenschaftlichen Vereins Neuvorpommerns und Rügens 10: 115-196.

Nowak, J., 1913. Untersuchungen über die Cephalopoden der oberen Kreide in Polen. III. Teil. Bulletin international de l'Académie des Sciences et Lettres de Cracovie, Classe des Sciences mathématiques et naturelles (B) 1913: 335-415.

Odin, G.S. (Ed.), 2001. The Campanian-Maastrichtian Stage Boundary. Characterisation at Tercis les Bains (France) and Correlation with Europe and other Continents (Developments in Palaeontology and Stratigraphy, 19). Elsevier (Amsterdam): xxviii $+881 \mathrm{pp}$

Odin, G.S., Courville, P., Machalski, M. \& Cobban, W.A., 2001. The Campanian-Maastrichtian ammonite fauna from Tercis (Landes, France); a synthetic view. In: Odin, G.S. (Ed.): The Campanian-Maastrichtian Stage Boundary. Characterisation at Tercis les Bains (France) and Correlation with Europe and other Continents (Developments in Palaeontology and Stratigraphy, 19). Elsevier (Amsterdam): 550-567.

Schönfeld, J., Schulz, M.-G., McArthur, J.M., Burnett, J., Gale, A., Hambach, U., Hansen, H.J., Kennedy, W.J., Rasmussen, K.L., Thirlwall, M.F. \& Wray, D.S., 1996. New results on biostratigraphy, palaeomagnetism, geochemistry and correlation from the standard section for the Upper Cretaceous white chalk of northern Germany (Lägerdorf-Kronsmoor-Hemmoor). Mitteilungen aus dem Geologisch-Paläontologischen Institut der Universität Hamburg 77: 545-575.

Schlottheim, E.F. von, 1813. Beiträge zur Naturgeschichte der Versteinerungen in geognostischer Hinsicht. In: Leonhard's Taschenbuch für die gesamte Mineralogie mit Hinsicht auf die neuesten Entdeckungen (1)7:3-134.

Schulz, M.-G., 1979. Morphometrisch-variationsstatistische Un- tersuchungen zur Phylogenie der Belemniten-Gattung Belemnella im Untermaastricht NW-Europas. Geologisches Jahrbuch A47: 3-157.

Schulz, M.-G., Ernst, G., Ernst, H. \& Schmid, F., 1984. Coniacian to Maastrichtian stage boundaries in the standard section for the Upper Cretaceous white chalk of NW Germany (LägerdorfKronsmoor-Hemmoor): Definitions and proposals. Bulletin of the Geological Society of Denmark 33: 203-215.

Sowerby, J., 1817. The Mineral Conchology of Great Britain, or coloured figures and descriptions of these remains of testaceous animals or shells, which have been preserved at various times and depths in the earth 2. Richard Taylor (London): 151-186.

Spath, L.F., 1922. On the Senonian ammonite fauna of Pondoland. Transactions of the royal Society of South Africa 10: 113-147.

Troelsen, J.C., 1937. Om den stratigrafiske Inddeling af Skrivekridt i Danmark. Meddelelser fra danske geologiske Forening 6: 260263.

Verbeek, J.W. 1983. The calcareous nannofossils from the Campanian and Maastrichtian rocks of southern Limburg (The Netherlands) and the adjacent Belgian area. Symposium on Cretaceous Stage Boundaries, Copenhagen 1983, Abstracts. University of Copenhagen (Copenhagen): 197-200.

Wagreich, M., Küchler, T. \& Summesberger, H., 2003. Correlation of calcareous nannofossil zones to the local first occurrence of Pachydiscus neubergicus (von Hauer) (Ammonoidea) in European Upper Cretaceous sections. Netherlands Journal of Geosciences 82: $283-288$ (this issue).

Ward, P.D. \& Kennedy, W.J., 1993. Maastrichtian Ammonites from the Biscay Region (France, Spain). The Paleontological Society Memoir 34: iv + 58 pp.

Weiss, W., 1999. Foraminiferal biostratigraphy of the marine Maastrichtian in northern Germany. In: Schulp, A.S., Jagt, J.W.M. \& Graaf, D.T. de (Eds): The 150th anniversary of the Maastrichtian Stage: a celebratory conference. Natuurhistorisch Museum Maastricht, 17-21 November 1999. Conference programme, abstracts and field guide: $58-59$.

Wicher, C.A., 1953. Mikropaläontologische Beobachtungen in der höheren borealen Oberkreide, besonders im Maastricht. Geologisches Jahrbuch 68: 1-26.

Zittel, K.A. von, 1884. Handbuch der Palaeontologie, 1(2)3. Cephalopoda. R. Oldenburg (München/Leipzig): 329-522. 